\title{
Typical Rainfall Distribution Pattern of Flood Event Caused by Tropical Cyclone at Bima City, West Nusa Tenggara, Indonesia
}

\author{
Rachna Sok ${ }^{1, *}$ \\ ${ }^{1}$ Street 275, Sangkat Boengkok I, Toul kok, Pnom Penh, CAMBODIA \\ "Corresponding authors: sokrachna007@gmail.com
}

SUBMITTED 9 April 2018 REVISED 18 October 2018 ACCEPTED 17 December 2018

\begin{abstract}
Tropical cyclones are the most serious meteorological phenomena that hit Bima city in December 2016. The strong winds and heavy precipitation associated with a typhoon significantly affect the weather in this city. The impact of a tropical cyclone on precipitation variability in Bima is studied using rainfall data for analyzing hourly rainfall distribution pattern during the event. Depend on the geographic situation and climate characteristic, the hourly rainfall distribution pattern of one area is different to others area. The research aims to analyze hourly rainfall distribution pattern in the form of the rainfall intensity distribution. This research is conducted using one automatic rainfall gauge in Bima city, West Nusa Tenggara province that obtained from Regional Disaster Management Agency (BPBD). The results showed that two events of rainfall were recorded. The first rainfall event was on $20^{\text {th }}$ to $21^{\text {st }}$ December 2016 with a total rainfall $191.4 \mathrm{~mm}$. The second rainfall event occurred on $22^{\text {nd }}$ to $23^{\text {rd }}$ December 2016 with a total rainfall $126.2 \mathrm{~mm}$. The rainfall distribution pattern has rainfall intensity peak at $45 \%$ of duration with cumulative rainfall reached $70 \%$. It was found there is no common pattern of temporal rainfall distribution for rainfall induced by tropical cyclones.
\end{abstract}

KEYWORDS Tropical cyclone; hourly rainfall distribution; automatic rainfall gauge

(C) The Author(s) 2018. This article is distributed under a Creative Commons Attribution-ShareAlike 4.0 International license.

\section{INTRODUCTION}

Tropical cyclones are the most serious meteorological phenomena (Wu \& Kuo, 1999). These tropical cyclones' tail hit Bima city at the end of December 2016. The strong winds and heavy precipitation significantly affected the weather in Bima city. Bima is a city of West Nusa Tenggara province that is located on the eastern part of the Sumbawa Island, Indonesia.

Flooding is a global phenomenon which causes widespread devastation, economic damages and loss of human lives (Jha, et al., 2012). Flooding of Padolo River at West Nusa Tenggara Province has caused significant damage in the city of Bima. Such flooding may occur without sufficient warning. According to the Regional Disaster Management Agency (BPBD of Bima City), the considerable flooding occurred from $20^{\text {th }}$ to $23^{\text {rd }}$ December 2016 which was affected by tropical cyclone called Yvette. This cyclone also hit northwestern Australian coast.

Study of rainfall pattern caused by such extreme condition is essential, especially for estimating flood hydrograph parameters such as the peak discharge and peak duration time. To study rainfall pattern, it needs at least hourly rainfall data record or even that has a shorter time interval. An automatic rainfall gauge is useful for providing the hourly rainfall data. In Bima city, the only one automatic rainfall gauge is Walikota rainfall station that belongs to Padolo River catchment area. It is useful to design the daily rainfall distribution or the hourly rainfall distribution patterns of the cyclonic rainfall for that region. However, there are problems encountered in the process of conducting such design since the available duration of rainfall may be too short, e.g., in a few days and the events are rare to occur. In Indonesia, the most frequent typical precipitation is high-intensity rainfall and short duration rainfall caused by small cyclones that generally occur during the transition from the dry season to rainy season or vice versa (BNPB, 20102014).

The study was conducted for Padolo River catchment area that its downstream part was located in Bima City administrative area and the upstream region is located in Bima Regency administrative area with the Latitude of $-8^{\circ} 27^{\prime} 32.4^{\prime \prime}$ and Longitude of $118^{\circ} 43^{\prime} 30.36^{\prime \prime}$. The total catchment area is of $260 \mathrm{~km}^{2}$ as shown in Figure 1. 


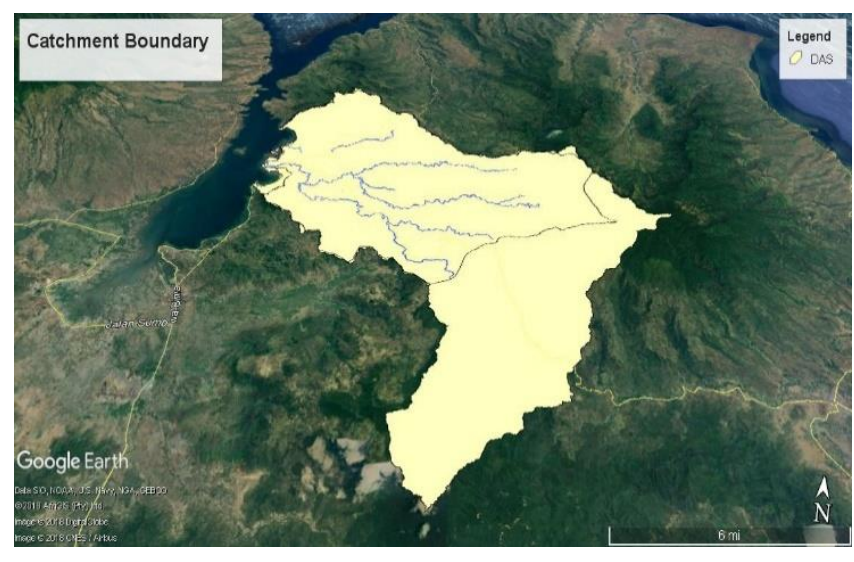

Figure 1. The shape of Padolo Catchment Area, upper left part belongs to Bima City administration, and the lower part belongs to Bima Regency administration

\section{LITERATURE REVIEW}

\subsection{Tropical Cyclone Rainfall}

A tropical cyclone (TC) is a cyclonic weather system with compact, centrally organized precipitation (Zick \& Matyas, 2016). It is also a cyclone originating in the tropics or subtropics. Although it generally resembles the extra-tropical cyclone of higher latitudes, there are significant differences, the principal one being the concentration of a large amount of energy into a relatively small area. They are infrequent in comparison with middle and high latitude storms, but they have a record of destruction far exceeding that of any other type of storm (United State Federal Government, 2002). Heavy rainfall, strong wind, large storm surge is the main effect tropical cyclone which mainly depends on the size, the intensity, and the location. According to the previous of research reports, typhoon occurrences that hit Taiwan Island mostly were caused by the tropical cyclone.

Blelloch \& Brand (1974) studied the effect of Taiwan Island to the intensity and direction of movement of 25 typhoon occurrences during 1960 - 1972 that approached or hit Taiwan. It was concluded that small typhoons (max sustained wind speed $<50$ knots/ 92.6 $\mathrm{Km} / \mathrm{jam}$ and vertical extent $<3 \mathrm{Km}$ ) tend to dissipate over the island. Medium typhoons (wind speed 50 $100 \mathrm{knots} / 92.6$ to $185.2 \mathrm{Km} / \mathrm{jam}$ and vertical extent about $6 \mathrm{Km}$ ) tend to produce secondary induced lows and high typhoons (wind speed > 100 Knots/ 185.2 $\mathrm{Km} / \mathrm{jam}$ and vertical extent about $10.7 \mathrm{Km}$ ).

Rainfall associated with tropical cyclones contributes a significant amount daily rainfall in Bima City. Rainfall is the main input in analyses of the hydrological balance of a watershed, which is the climatic attribute for providing the most significant interaction between the climatic elements and the physical aspects, according to Clarke and Silva (2004).

Study on the relation of rainfall intensity to the strength of tropical cyclone was done by Jiang et al (2006). The study found that the peak of rainfall intensity for over-land distribution is significantly different with those for over-ocean distribution. Data of hurricane Katrina (23-31 August 2005) were used in this study. The results also show the relation between potential rainfall one day before landfall and the maximum total rain over land.

Spatial-temporal distribution of rainfall induced by Nida Typhoon in Guangzhou District was studied (Zhang \& Chen, 2018). The result shows there were three temporal blocks of rainfall trains each has significant peak rainfall intensity of $10-34 \mathrm{~mm}$ /hour during three days rainfall.

\subsection{Rainfall Intensity}

The amount of rainfall per unit time referred to the intensity of rainfall which is commonly expressed in $\mathrm{mm} / \mathrm{hour}$. Therefore, the intensity of rainfall means the amount of precipitation/rainfall in a relatively short time (usually within less than 2 hours). According to Sosrodarsono and Takeda (1985), rainfall can be classified based on its intensity. The classification of rainfall intensity is shown as in Table 1 below.

Table 1. Rainfall intensity classification

\begin{tabular}{lll}
\hline Rainfall type & \multicolumn{2}{l}{ Rainfall intensity $(\mathrm{mm})$} \\
\cline { 2 - 3 } & 1 hour & 24 hours \\
\hline Very light rainfall & $<1$ & $<5$ \\
Light rainfall & $1-5$ & $5-20$ \\
Normal rainfall & $5-10$ & $20-50$ \\
Heavy rainfall & $10-20$ & $50-100$ \\
Extreme rainfall & $>20$ & $>100$ \\
\hline
\end{tabular}

The analysis of the relationship between two important parameters in the form of rainfall intensity and duration can be associated statistically with a frequency of occurrence that the results are presented as intensity-duration-frequency (IDF) graph (Loebis, 1992).

\subsection{Rainfall Distribution}

Temporal rainfall distribution can be depicted concerning hyetograph illustrating typical rainfall distribution pattern in the form of the relationship between rainfall depth and time as shown in Figure 2.

The intensity of rainfall varies in space and time, which depends on the geographical location and 
climate, and has a close relationship with the duration of rainfall (Tunas, et al., 2016)

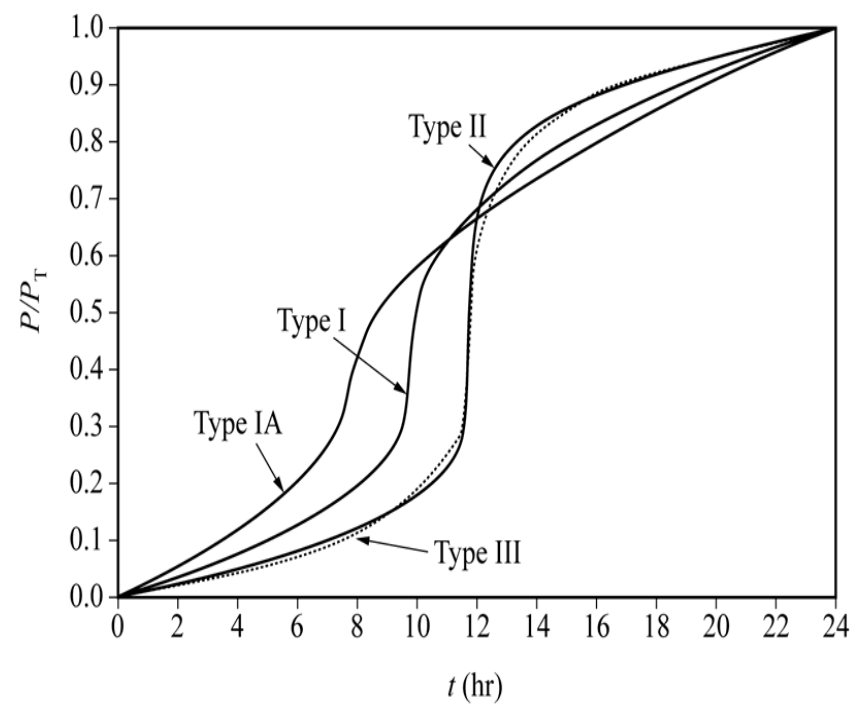

Figure 2. SCS rainfall hourly distribution

If the same rainfall duration produces different rainfall depth, the average rainfall intensity will be different. The relationship between rainfall intensity with time duration is described in the form of hyetograph. Hyetograph is histogram which illustrates rainfall depth or rainfall intensity with increasing time as abscissa and rainfall depth or intensity as ordinate. In principle, rainfall distribution patterns is expressed as the rain intensity can be obtained from automatic rainfall gauge, but if the data is not available, rainfall distribution patterns may be determined by hypothetical distribution models (Chow, et al., 1988) such as uniforms (uniform), triangle, Mononobe, alternating block method (ABM), and Tadashi Tanimoto (Table 2).

Table 2. Rainfall distribution of Tadashi Tanimoto

\begin{tabular}{lcccccccc}
\hline $\begin{array}{l}\text { Time } \\
\text { (hour) }\end{array}$ & 1 & 2 & 3 & 4 & 5 & 6 & 7 & 8 \\
\hline $\begin{array}{l}\text { Rainfall } \\
\text { depth (\%) }\end{array}$ & 26 & 24 & 17 & 13 & 7 & 5.5 & 4 & 3.5 \\
$\begin{array}{l}\text { Cumulative } \\
\text { rainfall (\%) }\end{array}$ & 26 & 50 & 67 & 80 & 87 & 92.5 & 96.5 & 100 \\
\hline
\end{tabular}

\section{MATERIALS AND METHODS}

This research only used one automatic rainfall gauge providing hourly rainfall data of one year (2016). Data analysis was conducted based on the hourly rainfall distribution pattern during tropical cyclone period that caused the flood in Bima city. The hourly rainfall data was obtained from BPBD of Bima City namely
Walikota rainfall station. Figure 3 depicted the position of all rainfall stations in this study area.

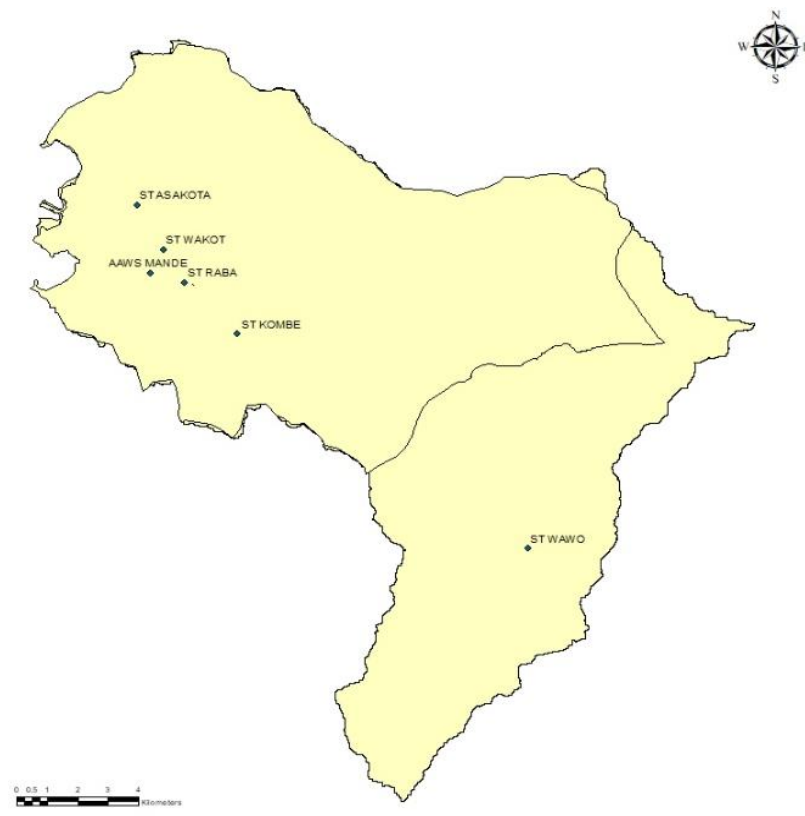

Figure 3. Rainfall gauges position

\subsection{Data Availability}

This study used secondary data obtained from BPBD. The data provides from this study were a map of the location of rainfall gauge stations and rainfall data from Walikota rainfall station (hourly rainfall data).

\subsection{Data Processing}

The stage of rainfall data processing performed in this study was:

a) Individual train of hourly rainfall data of Walikota rain gauge was separated.

b) Each train of hourly rainfall data was converted into cumulative hourly rainfall data.

c) Normalizing the cumulative hourly rainfall data to obtain rainfall hourly distribution.

d) Selecting the rainfall data affected by the Yvette tropical cyclone.

e) Discussion of the hourly rainfall distribution pattern.

f) Drawing the conclusion.

\section{RESULTS AND DISCUSSION}

\subsection{Typical Rainfall Distribution Pattern}

For analyzing of hourly rainfall distribution induced by the cyclone, two hourly rainfall distribution was used according to the eyewitnesses report. The first rainfall distribution was from 21:00 on 20 ${ }^{\text {th }}$ December 2016 
until 16:00 on $21^{\text {st }}$ December 2016. Figure 4 showed the hourly rainfall and cumulative rainfall chart. Based on Figure 4 , the tropical cyclone produced rainfall intensity up to $51 \mathrm{~mm} /$ hour at 4:00 on $21^{\text {st }}$ December. It was the highest rainfall intensity conveying great overflow from the river and causing large inundation.

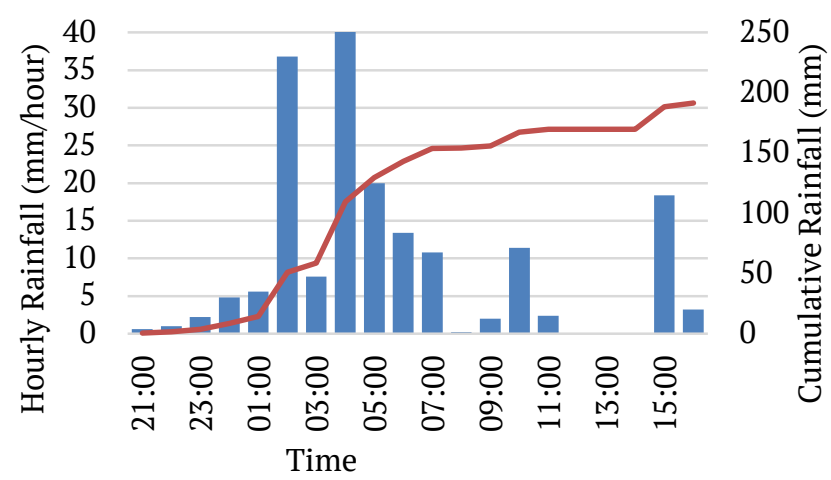

Figure 4. Precipitation and cumulative rainfall during $20^{\text {th }}$ $21^{\text {st }}$ December 2016

The second rainfall distribution pattern started from 21:00 on $22^{\text {nd }}$ December 2016 until 17:00 on $23^{\text {rd }}$ December 2016. According to Figure 5, hourly rainfall was up to $30 \mathrm{~mm} /$ hour at 03:00 on 23 $3^{\text {rd }}$ December 2016. Associating this heavy rainfall, the overland flood occurred again then damaged some houses.

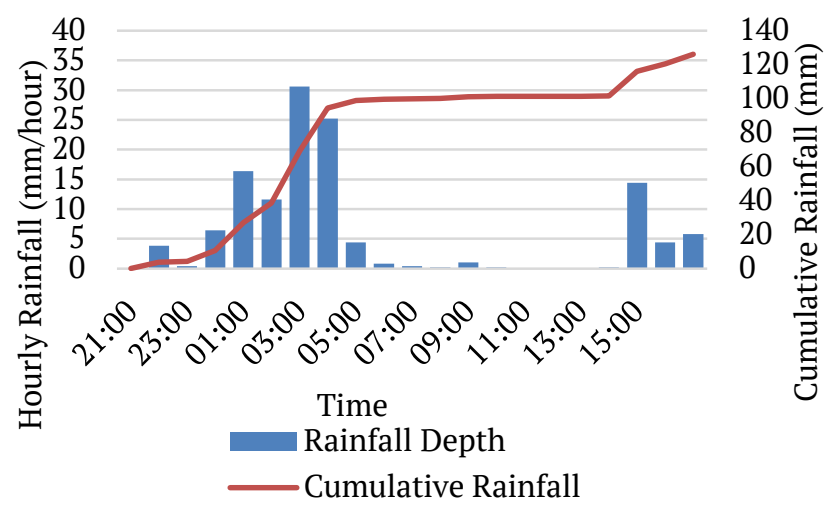

Figure 5. Precipitation and cumulative rainfall during $22^{\text {nd }}$ $23^{\text {rd }}$ December 2016

The chart of the percentage of cumulative - the percentage of the duration of both rainfall trains on $20^{\text {th }}-21^{\text {st }}$ December 2016 and on $22^{\text {nd }}-23^{\text {rd }}$ December 2016 with the average of cumulative percentage rainfall was presented in Figure 6. From Figure 6, it can be seen that the highest intensities occurred in the first part of rainfall (about $40 \%$ within $25 \%$ of the total of storm duration).

The maximum precipitation rainfall at Bima, for both rainfall events, was $38.1 \mathrm{~mm}$ with $35 \%$ of duration as can be seen in Figure 7. Thus, the possibility of flooding caused by a tropical cyclone of Bima City was approximately in the range of $20 \%$ and $70 \%$ within 10 $\%-60 \%$ duration. In Figure 7 , the other cases of Taiwan and India were also presented.

The table of the rainfall intensity, hourly duration of rain with the date of raining were presented in Table 3 and Table 4.

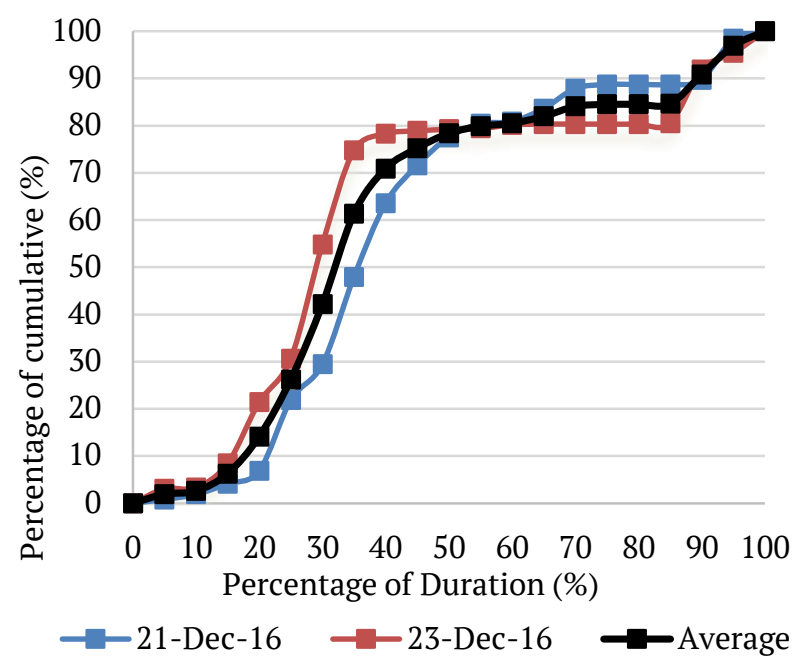

Figure 6. Rainfall distribution of long period

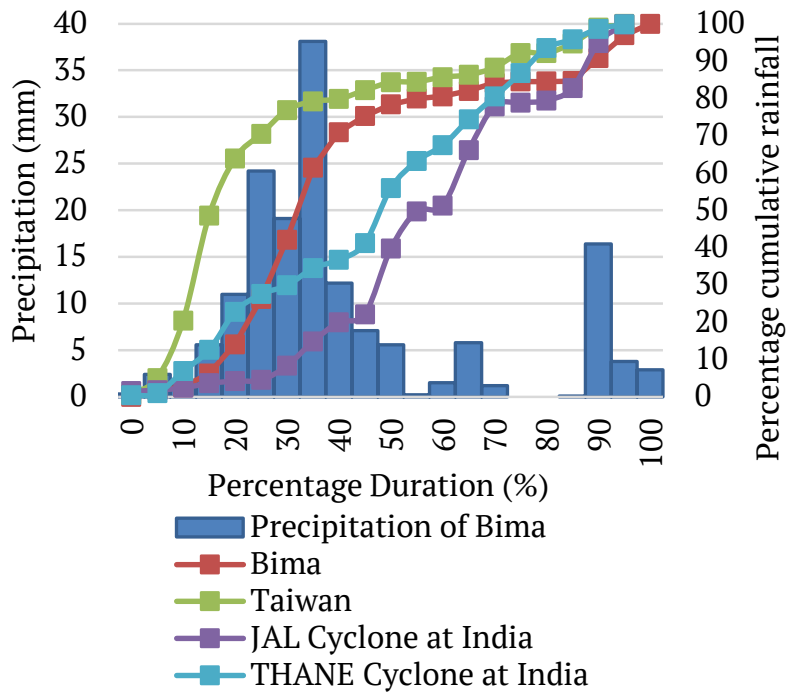

Figure 7. Precipitation and average of cumulative percentage rainfall 
Table 3. Rainfall Intensity during $20^{\text {th }}-21^{\text {st }}$ December 2012

\begin{tabular}{|c|c|c|c|c|c|c|c|}
\hline No & Date & Time & $\begin{array}{l}\text { Intensity } \\
\text { (mm/hour) }\end{array}$ & Depth (mm) & Cumulative (mm) & $\%$ Time & $\%$ Cumulative \\
\hline 0 & $20 / 12 / 2016$ & $21: 00$ & 0.6 & 0.6 & 0.6 & 0 & 0 \\
\hline 1 & $20 / 12 / 2016$ & $22: 00$ & 1 & 1 & 1.6 & 5.26 & 0.84 \\
\hline 2 & $21 / 12 / 2016$ & $23: 00$ & 2 & 2 & 3.8 & 10.53 & 1.99 \\
\hline 3 & $21 / 12 / 2016$ & 00:00 & 4.8 & 4.8 & 8.6 & 15.79 & 4.49 \\
\hline 4 & $21 / 12 / 2016$ & 01:00 & 5.6 & 5.6 & 14.2 & 21.05 & 7.42 \\
\hline 5 & $21 / 12 / 2016$ & 02:00 & 36.8 & 36.8 & 51.0 & 26.32 & 26.65 \\
\hline 6 & $21 / 12 / 2016$ & 03:00 & 7.6 & 7.6 & 58.6 & 31.58 & 30.62 \\
\hline 7 & $21 / 12 / 2016$ & 04:00 & 51 & 51 & 109.6 & 36.84 & 57.26 \\
\hline 8 & $21 / 12 / 2016$ & 05:00 & 20 & 20 & 129.6 & 42.11 & 67.71 \\
\hline 9 & $21 / 12 / 2016$ & 06:00 & 13.4 & 13.4 & 143.0 & 47.37 & 74.71 \\
\hline 10 & $21 / 12 / 2016$ & 07:00 & 10.8 & 10.8 & 153.8 & 52.63 & 80.36 \\
\hline 11 & $21 / 12 / 2016$ & 08:00 & 0.2 & 0.2 & 154.0 & 57.89 & 80.46 \\
\hline 12 & $21 / 12 / 2016$ & 09:00 & 2 & 2 & 156.0 & 63.16 & 81.50 \\
\hline 13 & $21 / 12 / 2016$ & $10: 00$ & 11.4 & 11.4 & 167.4 & 68.42 & 87.46 \\
\hline 14 & $21 / 12 / 2016$ & $11: 00$ & 2.4 & 2.4 & 169.8 & 73.68 & 88.71 \\
\hline 15 & $21 / 12 / 2016$ & $12: 00$ & 0 & 0 & 169.8 & 78.95 & 88.71 \\
\hline 16 & $21 / 12 / 2016$ & $13: 00$ & 0 & 0 & 169.8 & 84.21 & 88.71 \\
\hline 17 & $21 / 12 / 2016$ & $14: 00$ & 0 & 0 & 169.8 & 89.47 & 88.71 \\
\hline 18 & $21 / 12 / 2016$ & $15: 00$ & 18.4 & 18.4 & 188.2 & 94.74 & 98.33 \\
\hline 19 & $21 / 12 / 2016$ & $16: 00$ & 3.2 & 3.2 & 191 & 100.00 & 100.00 \\
\hline
\end{tabular}

Table 4. Rainfall Intensity during 22 ${ }^{\text {nd }}-23^{\text {rd }}$ December 2012

\begin{tabular}{llllllll}
\hline No & Date & Time & Intensity $(\mathrm{mm} /$ hour) & Depth $(\mathrm{mm})$ & Cumulative $(\mathrm{mm})$ & \% Time & \% Cumulative \\
\hline 0 & $22 / 12 / 2016$ & $21: 00$ & 0 & 0 & 0.0 & 0 & 0 \\
1 & $22 / 12 / 2016$ & $22: 00$ & 3.8 & 3.8 & 3.8 & 5.00 & 3.01 \\
2 & $22 / 12 / 2016$ & $23: 00$ & 0.4 & 0.4 & 4.2 & 10.00 & 3.33 \\
3 & $23 / 12 / 2016$ & $00: 00$ & 6.4 & 6.4 & 10.6 & 15.00 & 8.40 \\
4 & $23 / 12 / 2016$ & $01: 00$ & 16.4 & 16.4 & 27.0 & 20.00 & 21.39 \\
5 & $23 / 12 / 2016$ & $02: 00$ & 11.6 & 11.6 & 38.6 & 25.00 & 30.59 \\
6 & $23 / 12 / 2016$ & $03: 00$ & 30.6 & 30.6 & 69.2 & 30.00 & 54.83 \\
7 & $23 / 12 / 2016$ & $04: 00$ & 25.2 & 25.2 & 94.4 & 35.00 & 74.80 \\
8 & $23 / 12 / 2016$ & $05: 00$ & 4.4 & 4.4 & 98.8 & 40.00 & 78.29 \\
9 & $23 / 12 / 2016$ & $06: 00$ & 0.8 & 0.8 & 99.6 & 45.00 & 78.92 \\
10 & $23 / 12 / 2016$ & $07: 00$ & 0.4 & 0.4 & 100.0 & 50.00 & 79.24 \\
11 & $23 / 12 / 2016$ & $08: 00$ & 0.2 & 0.2 & 100.2 & 55.00 & 79.40 \\
12 & $23 / 12 / 2016$ & $09: 00$ & 1 & 1 & 101.2 & 60.00 & 80.19 \\
13 & $23 / 12 / 2016$ & $10: 00$ & 0.2 & 0.2 & 101.4 & 65.00 & 80.35 \\
14 & $23 / 12 / 2016$ & $11: 00$ & 0 & 0 & 101.4 & 70.00 & 80.35 \\
15 & $23 / 12 / 2016$ & $12: 00$ & 0 & 0 & 101.4 & 75.00 & 80.35 \\
16 & $23 / 12 / 2016$ & $13: 00$ & 0 & 0 & 101.4 & 80.00 & 80.35 \\
17 & $23 / 12 / 2016$ & $14: 00$ & 0.2 & 0.2 & 101.6 & 85.00 & 80.51 \\
18 & $23 / 12 / 2016$ & $15: 00$ & 14.4 & 14.4 & 116.0 & 90.00 & 91.92 \\
19 & $23 / 12 / 2016$ & $16: 00$ & 4.4 & 4.4 & 120.4 & 95.00 \\
20 & $23 / 12 / 2016$ & $17: 00$ & 5.8 & 5.8 & 126.2 & 100.00 \\
\hline
\end{tabular}

\subsection{Discussion}

The behavior of tropical cyclones is affected by many factors such as environmental surrounding them. The comparison of cumulative tropical cyclone rainfall distribution which occurred at Bima city to that of Taiwan Island and India showed that the patterns were significantly different. This difference might be caused by the different location relative to the eye of the cyclone and the track of the cyclone movement.

The typhoon which attacked Taiwan Island on $17^{\text {th }}$ July 2008 at 15:00 until on $19^{\text {th }}$ July 2008 at 18:30 from the northern and southern direction caused a big flood event and landslide (Chang et al., 2017). The maximum of rainfall on this flood event occurred around at 22:00 midnight of $17^{\text {th }}$ July 2008 with $150 \mathrm{~mm}$ of the highest 
rainfall intensity. According to Figure 7, the cumulative rainfall of flood event at Taiwan started at the first part of the curve. The peak of cumulative rainfall was $80 \%$ with the percentage duration between $5 \%-50 \%$.

Another researcher, Janapatia (2017) studied the two kinds of cyclones which hit some parts of southern India. The first cyclone was JAL cyclone induced precipitation on $7^{\text {th }}$ and $8^{\text {th }}$ November 2010 over Kadapa. The rainfall started on $7^{\text {th }}$ November 2010 at 1:00 am until the end of rainfall on $8^{\text {th }}$ November 2010 at 1:00 am. The highest rainfall intensity was on $7^{\text {th }}$ November 2010 at 18:00 with rainfall intensity of 58 $\mathrm{mm}$. From Figure 7, it can be seen at the rainfall pattern of JAL cyclone at India started at the first part of the curve with the peak cumulative $25 \%$ between 5 $\%-25 \%$ duration. The decreasing of water started for a few hours, then went up again with the peak of cumulative rainfall $60 \%$ between $50 \%-60 \%$ duration.

The second cyclone type, THANE was induced precipitation on $29^{\text {th }}$ and $30^{\text {th }}$ December 2011 was measured by laser baser disdrometer called PARSIVEL at Gadanki. The rainfall started at 10:00 am on $29^{\text {th }}$ December 2011 and finish at 18:00 on $30^{\text {th }}$ December 2011. The highest rainfall at 02:00 on $30^{\text {th }}$ December 2011 with rainfall intensity of $32 \mathrm{~mm}$. Based on Figure 7 , the peak cumulative rainfall of this flood event was $45 \%$ between $45 \%$ - $60 \%$ duration. The precipitation decreased a few hours then started with the high precipitation that peak of cumulative rainfall which was $75 \%$ between $60 \%$ - $70 \%$ duration.

In contrast, Tropical cyclone which hit Bima city in this study case had a lifetime four day which caused two big flood occurrences. The highest rainfall intensity for the first time on $21^{\text {st }}$ December 2016 was $56 \mathrm{~mm}$ at 4:00 am. The highest rainfall intensity of second time was $30 \mathrm{~mm}$ at 3:00 am on $23^{\text {rd }}$ December 2016. The peak of cumulative rainfall was $70 \%$ between $10 \%-60 \%$ duration.

The direction of typhoon movement which has induced high precipitation to three areas such as Taiwan, India and Bima city always changes and depend on the situation of areas and the characteristic of climate. The precipitation can be very high, high or light depends on the area and distance to the eye of the cyclone. According to these cases, it is known that typhoon in Taiwan and Bima causes flooding earlier than that of India based on Figure 7, the peak cumulative rainfall of both cases started at the beginning part of duration which means faster than in India.

\section{CONCLUSION}

Rainfall data from the only one automatic rainfall gauge in Bima city provided hourly cumulative rainfall distribution pattern which is caused by the tropical cyclone. This rainfall distribution pattern has a peak of rainfall intensity at $45 \%$ of rainfall duration with cumulative rainfall depth that has already reached $70 \%$. For the Taiwan case, the rainfall distribution pattern has peak rainfall intensity at $15 \%$ of rainfall duration with cumulative rainfall of $60 \%$. Therefore, the flood occurred earlier. For the India case, the JAL cyclone has no clear peak rainfall intensity, while the THANE cyclone has a peak at $70 \%$ of rainfall duration with cumulative rainfall of $75 \%$. That means the flood occurred later. It is found there is no common pattern of temporal rainfall distribution for rainfall induced by tropical cyclones. It might be a common pattern if the relative distance to the cyclone eye and its track direction angle are included as the other factors.

\section{ACKNOWLEDGMENTS}

The researcher would like to express appreciation to the Department of Civil and Environmental Universitas Gadjah Mada for contribution to improve the capacity of knowledge about disaster management and also would like to appreciate for good advice in this work to the academic supervisors.

\section{REFERENCES}

Blelloch, J. W. \& Brand, S., 1974. Changes in the Characteristics of Typhoons Crossing the Island of Taiwan. Monthly Weather Review, Volume 102, pp. 708713.

BNPB, 2010-2014. National Disaster Management Plan. [Online].

Chang, J. M. et al., 2017. Characteristics of rainfall intensity, duration, and kinetic energy for landslide triggering in Taiwan. Engineering Geology, Volume 231, pp. 81-87.

Chow, V. T., Maidment, D. R. \& Larry, W., 1988. Applied Hydrology. MacGraw-Hill, Inc.

Clarke, R. T. \& Silva, B., 2004. Análise estatística de chuvas intensas na bacia do rio São Francisco. Revista Brasileira de Meteorologia. 
Janapatia, J., 2017. A study on raindrop size distribution variability in before and after landfall. Journal of Atmospheric and Solar-Terrestrial Physics,, Volume 159, pp. 23-40.

Jha, A. K., Bloch, R. \& Lamond, J., 2012. Cities and Flooding: A Guide to Integrated Urban Flood Risk Management for the 21st century. Washington D.C: The World Bank.

Jiang, H., Halverson, J. B. \& Sim, J., 2006. Difference of Rainfall Distribution for Tropical Cyclones Over Land and Ocean and Rainfall Potential Derived from Satellite Observations and its Implication on Hurricane Landfall Flooding Prediction. [Online] Available at:

https://www.google.com/url?sa=t\&rct $=$ i \& $q=\& e s r c=s$ \&source=web \&cd $=1 \& c a d=$ rja $\&$ uact $=8$ \&ved=2ahUKE wjP8MvJ0MvdAhXHLY8KHcUdB-

EOFjAAegOICRAC \&url=https\%3A\%2F\%2Fams.confex .com\%2Fams\%2Fpdfpapers\%2F108764.pdf\&usg=AOv Vaw0lUx41sfAfVvcrIGFc5bxN

[Accessed 21 September 2018].

Loebis, J., 1992. Design Flood for Hydraulic Structure. Ministry of Public Works.

Sosrodarsono, S. \& Takeda, K., 1985. Hydrology for Irrigation, Jakarta: PT. Pradnya Paramita.
Tunas, I. G., Nadjadji, A. \& Lasminto, U., 2016. Analysis of Dominant Rainfall Distribution Pattern for Flood Hydrograph Prediction. Makassar.

United State Federal Government, 2002. Tropical Cyclone, Chapter 35 of the American Practical Navigator. [Online]

Available at: https://en.wikisource.org/wiki/The_American_Practic al_Navigator/Chapter 35

[Accessed 21 September 2018].

Wu, C. C. \& Kuo, Y. H., 1999. Typhoons Affecting Taiwan: Current Understanding and Future Challenges. American Meterology Society.

Zhang, J. \& Chen, Y., 2018. Typhoon Nida's rainfall Characteristics in Guangzhou City based on Doppler Radar Estimation. IOP Publishing.

Zick, S. E. \& Matyas, C. J., 2016. A Shape Metric Methodology for Studying the Evolving Geometries of Synoptic-Scale Precipitation Patterns in Tropical Cyclones. Annals of the American Association of Geographers, 106(6), pp. 1217-1235. 
[This page is intentionally left blank] 